\title{
LA PARODIA EN EL TIEMPO
}

\author{
JUAN CAMPESINO
}

Centro Nacional de Investigación, Documentación e Información Teatral Rodolfo Usigli

\section{La parodia en la antigüedad: repetición y diferencia ${ }^{1}$}

En su Poética (c. 335 a. C.)를 Aristóteles consigna a Hegemón de Taso (s. v a. C.) como el primer autor de parodias y lo incluye en el grupo de poetas, en el que también figuran los comediógrafos, que imitan hombres peores que la media. Asimismo, atribuye a Homero el Margites, un poema épico-burlesco, probablemente del siglo $\mathrm{v}$ a. C., sobre un tonto que todo lo hace al revés, para agregarlo a la comedia en el común denominador de la poesía que hace reír

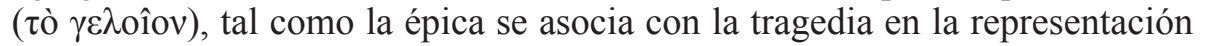
de acciones grandes y terribles ${ }^{3}$. Por su parte, en su Banquete de los eruditos (c. 200), a su vez una parodia del modelo simposiaco, Ateneo cita a Polemón de Atenas que, en su Contra Timeo (s. III a. C.), considera inventor del género a Hiponacte de Efeso (s. VI a. C.) ${ }^{4}$, continuador de Arquíloco - a quien suele atribuirse la invención de la sátira- y cómo él, yambógrafo.

${ }^{1}$ Tomo el binomio de Linda Hutcheon, quien en A Theory of Parody: The Teachings of Twentieth-Century Art Forms (University of Illinois Press, Urbana y Chicago, 2000, págs. 32, 37,65 y 101), lo recupera de Gilles Deleuze para referirse en específico a la parodia contemporánea $\mathrm{y}$, curiosamente, para distinguirla de sus anteriores manifestaciones.

2 1448a, 10-15.

${ }^{3}$ Véase 1449 a, 1 y sigs.

${ }^{4}$ Cf. Ateneo, XV, 698b-99a. 
A juzgar por los hexámetros que cita Ateneo, la parodia de Hiponacte consistía en una épica burlesca que evocaba la epopeya homérica, lo que también se deduce de la Gigantomaquia con la que Hegemón triunfó en Atenas y de la Deilíada, compuesta por su contemporáneo Nicócares y mencionada por Aristóteles. Datada entre los siglos I y III a. C., la anónima Batracomiomaquia constituye la muestra más antigua de esta clase de poemas. Se trata de una breve epopeya burlesca en hexámetros que ridiculiza el modelo homérico y cuyos héroes son batracios y roedores que, a guisa de armas, utilizan agujas, cáscaras de nuez y conchas de caracol. En esta gesta, como en la Ilíada, los dioses del Olimpo conviven con los seres mundanos: «¿Quiénes de los inmortales vais a ayudar a las ranas y quiénes a los ratones? $\nu^{5}$, pregunta al consejo olímpico Atenea, haciendo mofa de lo arbitraria que resulta la intervención de los dioses en la gesta homérica.

Sobre el origen del vocablo $\pi \alpha \rho \omega \delta i ́ \alpha$ parece no haber desacuerdos, como

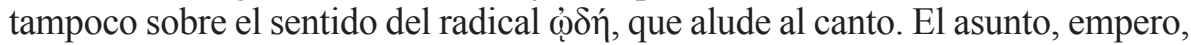
se complica en lo tocante al prefijo $\pi \alpha \rho \alpha ́$ que, tal como ocurre en la actualidad, entre los griegos probablemente atendía tanto a la acepción aditiva (a partir de, junto a) como a la sustractiva (en contra de, en oposición a). En su connotado artículo «ПАР $\Omega \mathrm{I} \Delta \mathrm{IA} »$, Fred Householder se refiere únicamente a la primera acepción para hablar de la parodia antigua como de un «canto que imita con una ligera variación» ${ }^{6}$, si bien menos de una década después, en su artículo «The Basis of Ancient Parody», F. J. Lelièvre hará mención de la segunda, subrayando con ello la ambigüedad del prefijo ${ }^{7}$. Independientemente de esta peculiaridad etimológica, lo cierto es que, sin limitarse a los autores de épicas burlescas en hexámetros, en su repaso de la parodia, Ateneo incluye a poetas como Sópatro de Pafos (s. III a. C.), autor de viñetas cómicas $(\Phi \alpha \kappa \eta \tilde{)})^{8}$, así como a Epicarmo y Cratino (s. VI a. C.) entre los comediógrafos; a éstos habría que añadir, además, a los responsables de las épicas burlescas en yambos de las que habla Gilbert Murray', y también a los autores de silos ( $\left.\sigma \dot{i} \lambda \lambda_{0 \imath}\right)$, especie de sátira filosófica en hexámetros cuya invención se atribuye a Timón (ss. IV y III a. C. $)^{10}$, y de las amalgamas de citas llamadas centones paródicos a los que se refiere Margaret Rose"11, y finalmente a Sofrón y su hijo Jenarco (ss. v y IV a. C.), creadores del $\mathrm{mimo}^{12}$.

${ }^{5}$ Vv. 173-174, en Himnos homéricos; Batracomiomaquia (trad. M. García), Akal, Madrid, 2000, pág. 260.

${ }^{6}$ En Journal of Classical Philology, 39, 1, 1944, pág. 2.

7 En Greece and Rome, 1, 2, 1954, pág. 66 y sigs.

$8 \mathrm{Xv}, 702$.

${ }^{9}$ Cf. Historia de la literatura clásica griega (trad. E. Soms), Albatros, Buenos Aires, 1947, pág. 76.

${ }^{10}$ Véase «Silloi», en A. Preminger (ed.), The New Princeton Encyclopedia of Poetry and Poetics, Princeton University Press, Nueva Jersey, 1993, pág. 1148.

11 Véase M. Rose, Parody: Ancient, Modern, and Post-Modern, Cambridge University Press, 1993, págs. 16-17.

12 Véase A. Melero, «El mimo griego», Estudios Clásicos, 25, 86, 1981-1983, pág. 21. Al margen de esta tradición, Benjamin Foster han identificado elementos paródicos en un manuscrito 


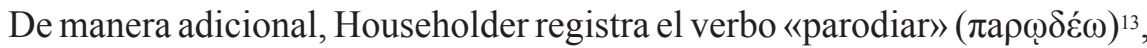
que aparece en los comentarios de la escolástica aristofánica (s. IV a. C. en adelante) en referencia a la citación burlesca mediante la que, en su Pluto, por ejemplo, Aristófanes alude a Hesíodo ${ }^{14}$. Asimismo, en las glosas a Los acarnienses, el término $\pi \alpha \rho \omega \delta$ ía designa un procedimiento análogo, siendo Eurípides el autor imitado ${ }^{15}$. En ambos casos, nótese, el modelo consta de unas cuantas palabras y se lo reconfigura en los linderos de un verso, lo que significa que, lo mismo que hoy día, entre los griegos el sentido de la voz 'parodia' admitía así un género poético como la épica burlesca que una técnica de citación cómica contenida ora en una frase, ora a lo largo de una obra y, desde luego, en todas las variantes intermedias.

Esta amplitud semántica la heredará la retórica latina. Así, en el primer siglo de

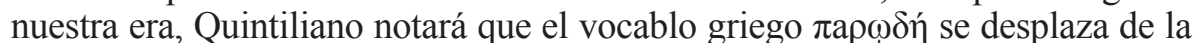
nominación de un canto compuesto a imitación de otros a la designación de un procedimiento de citación en verso o en prosa ${ }^{16}$, procedimiento que el rétor agrupa entre las agudezas que, mediante la ficción de las palabras y no de las acciones, mueven a risa al auditorio, y que puede consistir en la creación de versos semejantes a otros conocidos ${ }^{17}$. La distinción la toma el de Calahorra de Cicerón, quien hacía más de un siglo había dividido las fuentes de lo risible en aquellas compuestas de palabras y aquellas otras ancladas en la situación ${ }^{18}$. Pese a no referirse directamente a la parodia, entre las gracias basadas en la palabra Cicerón incluye la integración al discurso propio de un verso ajeno, «ya tal cual, ya con una ligera modificación, ya una parte del mismo» ${ }^{19}$. Con dicha amplitud en mente, Jean-Pierre Cèbe observa elementos paródicos prácticamente en todos los ámbitos de la expresión cultural de Roma ${ }^{20}$. En primer lugar, en la comedia de Plauto (ss. II y III a. C.) y, en menor medida, de Terencio (s. II a. C.), en la que identifica caricaturizaciones y procedimientos paródicos en diversos niveles de la representación y, en segundo, en los autores de sátiras, tanto de la vertiente tradicional que propugnan Lucilio (s. II a. C.), Horacio (s. I a. C.) y Juvenal (ss. I y II), como de la llamada menipea, entre cuyos exponentes se cuentan Varrón (s. I a. C.), Séneca y Petronio (s. I).

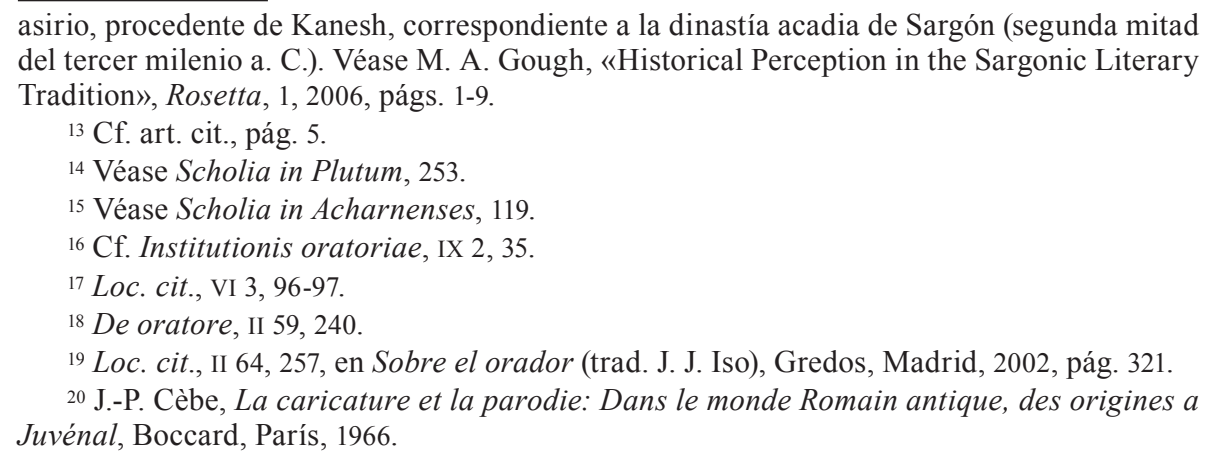




\section{Edad Media y Renacimiento}

Si la Edad Media no abunda en reflexiones teóricas sobre la parodia, cosa opuesta sucede con la literatura paródica, cuya prolijidad evidencia el florecimiento de la cultura popular. En términos estrictamente literarios, cabe subrayar el registro del término en la Suda (s. X), en referencia a un «texto en el que la tragedia se convierte en comedia» ${ }^{21}$, entrada que, apegándose a la tradición grecolatina, da cuenta de géneros heredados por la literatura medieval, tales como la épica burlesca y la menipea.

$\mathrm{Al}$ margen de éstos y de otros poemas tradicionales, aparece en los albores del cristianismo una nueva clase de parodia que toma como modelo los textos de la liturgia, considerados, como anota Martha Bayless, canónicos y no ficticios $^{22}$. La multiatribuida Cena Cypriani, una breve narración en prosa (se sabe de posteriores versiones en verso) que reúne una colección de personajes bíblicos para la celebración de unas bodas, constituye el exponente de mayor resonancia en este marco, lo que seguramente se debe a su temprano origen, entre los siglos IV y v, si bien junto a ella se produce un catálogo bastante significativo que incluye títulos como el Apacalypsis Goliae, el Salomon et Marculfus, ambos de la alta edad media y, en fechas posteriores, el Garcineida y el Sermo contra abstinentiam ${ }^{23}$.

De manera paralela, Danuta Shanzer documenta la proliferación, durante la Alta Edad Media, de obras que parodian textos relativos a otros ámbitos del conocimiento; obras como los Epítomes y las Epístolas de Virgilio Maro Gramático (siglo VII), escritos a imitación de las gramáticas de la época, como la Cosmografía de Aethicus Ister (siglos VII-VIII), parodia de la geografía y la etnografía enciclopédicas en la mejor tradición de Luciano, y como la versión paródica del Pactus legis salicae ${ }^{24}$, hallada junto a un manuscrito del siglo VIII del tratado sálico en materia penal y concerniente a la posesión de sustancias intoxicantes ${ }^{25}$.

${ }^{21} \mathrm{Pi}, 715$. Los orígenes de esta definición cabe buscarlos en los comentarios de la escolástica aristofánica al respecto de la citación paródica de Eurípides en el verso 8 de Los acarnienses. En este punto, la edición griega de Friedrich Dübner parece más completa que la de William Rutherford que, pese a su bilingüismo, omite el pasaje en cuestión. Véanse, respectivamente, Scholia graeca in Aristophanem, Didot, París, 1842, pág. 2, y Scholia aristophanica, Macmillan, Londres, II, 1896, pág. 258.

${ }_{22}$ Parody in the Middle Ages: The Latin Tradition, University of Michigan Press, Ann Arbor, 1996, pág. 1.

${ }^{23}$ Cf. loc. cit., págs. 13, 19 y sigs.

${ }^{24}$ Cf. «Laughter and Humour in the Early Medieval Latin West», en G. Halsall (ed.), Humour, History and Politics in Late Antiquity and the Early Middle Ages, Cambridge University Press, 2002, pág. 26.

${ }^{25} \mathrm{Al}$ conjunto de la literatura cómica de la Edad Media y el Renacimiento, en el que, entre otros, comprende el repertorio de la parodia sacra y, desde luego, la obra de Rabelais, Mijaíl Bajtín lo bautizó realismo grotesco, un sistema cultural basado en el desplazamiento de lo sublime y lo etéreo a los terrenos del cuerpo, bajos, sensuales y prosaicos. Para el ruso, no obstante, esta degradación es al mismo tiempo destrucción y renovación, en apego a los términos 
Por lo que a la teoría respecta, sin embargo, habrá que esperar hasta 1561 para que un humanista como Julio César Escalígero deposite su interés, aunque brevemente, en la parodia. La novedad del italiano, que no en su visión general del concepto, análoga a la del Suidae lexicon, se halla en la introducción de los términos latinos inverso y ridiculus para referirse al tratamiento paródico de las fuentes altas y nobles ${ }^{26}$. Por lo demás, Escalígero sigue a Aristóteles y, en particular, a Vincenzo Maggi que, en su De ridiculis (1550), expone una aproximación renacentista al universo literario que el estagirita denomina «tò $\gamma \varepsilon \lambda \mathrm{oîov}\rangle^{27}$.

\section{Las lenguas nacionales: parodia y atribución}

La entrada del término «parodia» (parody, parodie...) a las lenguas nacionales data de entre finales del siglo XVI y principios del XVII. Su ingreso al español no parece estar documentado, pero en inglés figura por primera vez en Every Man in his Humour, de Ben Jonson, drama escrito en $1598^{28}$, mientras que en 1614 se autoriza ya su uso en francés ${ }^{29}$. En este contexto, la semántica del vocablo se amplía hasta llegar a comprender, apenas en el siglo XVII, un amplio rango de procedimientos que Henryk Markiewicz agrupa del siguiente modo: (1) el empleo cómico de un fragmento serio mediante su remodelación o su incorporación a un contexto nuevo; (2) la remodelación de una obra seria

del carnaval, que identifica como su origen primigenio. Cf. La cultura popular en la Edad Media y en el Renacimiento. El contexto de François Rabelais (trad. J. Forcat y C. Conroy), Alianza, Madrid, 2003, págs. 7-34. Cabe, a propósito, reprochar a Bajtín el desliz de catalogar la cultura popular de la Edad Media y el Renacimiento, y con ella su fuente materna, en el orden de lo no oficial, cuando es un hecho que, a pesar de su antiguo origen, el carnaval se liga a la liturgia, en los días previos al miércoles de ceniza, como reverso y antesala de la cuaresma. Caso atípico, en este sentido, resulta el del indiano Pedro Suárez de Mayorga. Procesado por la traducción de un tratado de quiromancia y condenado, en 1584, por la Inquisición novohispana, a Suárez de Mayorga le fue incautado el manuscrito de un oráculo paródico, escrito a imitación de otros muchos que a la sazón gozaban de popularidad entre los juegos de salón. Sin constituir el ilícito impugnado, se sabe que la posesión del Mofarandel fue uno de los elementos probatorios que encausaron la condena por superstición, hecho que aún hoy, a la luz del texto y su contexto, se antoja inexplicable. Véase M. Peña, «Prólogo» a Mofarandel de los oráculos de Apolo, Universidad Nacional Autónoma de México/El Equilibrista, 1991, págs. 9-30.

26 «Est igitur Parodia Rhapsodia inversa mutatis vocibus ad ridicula sensum retrahens»: Poetice, I 42.

${ }^{27}$ «Para reír»: Poética, 1449a, 1. Véanse, al respecto, Rose, op. cit., pág. 9, y J. C. Pueo, Ridens et ridiculus: Vincenzo Maggi y la teoría humanista de la risa, Universidad de Zaragoza, 2001. En adelante, sobre todo en el marco de la teoría contemporánea y a causa de sus connotaciones peyorativas, el calificativo «ridículo» y su variante verbal «ridiculizar» socavarán el consenso a propósito de las filiaciones cómicas de la parodia, alimentando más de una polémica bizarra y estéril, lo que también debe decirse de «inverso» y «travesti».

28 Véase Y. Ikegami, «A Linguistic Essay on Parody», Linguistics, 55, 1969, pág. 20.

${ }^{29}$ Apud D. Sangsue, La parodie, Hachette, París, 1994, pág. 16. 
con propósitos satíricos destinados a ridiculizar, no el modelo, sino las costumbres contemporáneas; (3) el traslado de una obra seria a otra obra seria de distinto contenido, como en el Kontrafaktur (música religiosa compuesta a semejanza de canciones paganas), y (4) cualquier imitación de una obra sin coloración cómica ${ }^{30}$.

Con todo, una de las primeras definiciones modernas, por lo comprensiva y precisa, se halla, redactada en latín a propósito del mote griego, en el Tesoro de la lengua griega (1676), de William Robertson ${ }^{31}$. El lexicógrafo comienza por consignar, apoyado en Ateneo, la acepción más antigua del término: canto compuesto a imitación de otros pero con variaciones, para luego citar a Quintiliano e incluir la imitación de cualquier clase de discurso; en seguida, no obstante, agrega de su cosecha un valioso punto cuando se refiere a la parodia como «alteración jocosa de un verso con una transferencia distintiva de la argumentación $\rangle^{32}$, noción que, pasando casi desapercibida para la escolástica contemporánea, sobresale por sus implicaciones en el marco de la teoría moderna sobre el fenómeno. Así, será recogida en 1730 por Du Marsais quien, siguiendo a su maestro puntualmente, empleará el término francés 'raillierie' ahí donde aquél habla de «jocose $\rangle^{33}$. Du Marsais da un paso adelante en dos sentidos: incorpora, por un lado, la noción de «original» para referirse al modelo parodiado, situando el placer de la parodia en la percepción del contraste entre éste y su réplica y, por otro, toma en cuenta la atribución del texto paródico a un sujeto menos serio que el original. En adición, al identificar el radical $\pi \alpha \rho \alpha ́$ con el prefijo latino juxta, el francés aporta una solución anticipada a la polémica que más tarde mediará entre Householder y Lelièvre.

En una línea paralela se halla, en 1823, la definición de Isaac D’Israeli, para quien la parodia consiste en una «obra compuesta sobre otra obra pero transferida a un sujeto distinto mediante una sutil alteración de las expresiones $\rangle^{34}$. El móvil de la alteración, dice el británico, puede ser «a sport of fancy, the innocent child of mirth; or a satirical arrow drawn from the quiver of caustic criticism $\rangle^{35}$. He aquí una distinción que, olvidando, como hace, que todo cambio se traduce en una separación y que esta última se halla en el origen mismo de la palabra «crisis», traerá problemas a la teoría contemporánea, empeñada, hasta ahora sin éxito, en establecer diferencias claras y positivas entre sátira y parodia. A diferencia de Robertson, D'Israeli es bien conocido por los académicos contemporáneos y, empero, éstos se han fijado en la en apariencia excluyente dualidad lúdico-crítica de la parodia y no en otro aspecto, para mí

30 «On the Definitions of Literary Parody», en To Honor Roman Jakobson. Essays on the Occasion of his Seventieth Birthday, La Haya y París, Mouton, 1967, II, pág. 1265.

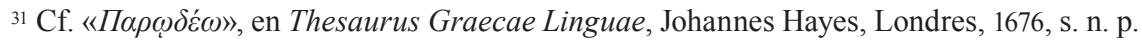

32 «[Q]uum alterius Poétae versus, jocose in aliud argumentum transferuntur»: loc. cit.

${ }^{33}$ Cf. Des tropes, David, París, 1757, pág. 273 y sigs.

${ }^{34}$ Curiosities of Literature, Routledge, Londres, II, 1858, pág. 454.

${ }^{35}$ Loc. cit., págs. 454-455. Conservo el original por las dificultades que encierra la traducción de «fancy». 
de mayor jerarquía, que habita en la transferencia del texto de un sujeto a otro. Como se verá en adelante, la problemática de la atribución paródica rara vez ha merecido atención por parte de los teóricos del siglo XX, siendo, como es, una cuestión de primordial interés.

Por su parte, en su Essai sur la parodie chez les Grecs, chez les Romains et chez les modernes, de 1870, Octave Delepierre recupera de un tratado de 1747 sobre la poesía francesa una definición, con la que conviene, de la que D’Israeli parece haber tomado la suya punto por punto: «La parodia - cita Delepierre-, hija primogénita de la sátira, es tan antigua como la poesía misma. Es parte de su esencia sustituir por un nuevo sujeto a aquel que parodia; en lugar de los sujetos serios, nuevos sujetos ligeros y bromistas que emplean, en lo posible, las expresiones del autor parodiado ${ }^{36}$. Asimismo, señala Gerard Genette, el propio Delepierre omite la referencia a su fuente cuando especula, en una nota al texto, sobre un hipotético público aburrido de la Ilíada y la Odisea y un rapsoda que, para captar la atención, recita breves poemas compuestos más o menos con los mismos versos del modelo homérico pero con variaciones de sentido que divierten al público ${ }^{37}$. Al margen de la omisión (Genette da con la fuente en la edición de 1759 del diccionario de Richelet) ${ }^{38}$, el cambio de sujeto luce tan importante para Delepierre que a él atribuye la clave de la parodia, descartando de su dominio obras, a las que denomina burlescas ${ }^{39}$, como el Virgile travesti, de Scarron, y la Henriade travesti, en las que personajes tomados de obras anteriores intervienen en contextos ajenos ${ }^{40}$. En un sentido teórico, el historiador belga da en el clavo al poner de relieve el carácter atributivo de la parodia, pero deja de observar, sin más, que el Eneas de Scarron, con su socarronería y su vulgar contexto, dista mucho de ser el de la épica fundacional de Roma; ni se comporta ni se expresa como éste, por lo tanto, ambos no son el mismo personaje.

A esta progresión de ideas en la que alternan francos y anglosajones se suma otra cuyo origen se debe al romanticismo alemán y en cuyo centro brilla el complejo filosófico expuesto por Friedrich Schlegel en sus múltiples fragmentos. En los del Liceo (1787), por ejemplo, califica la ironía socrática de «autoparodia», una licencia, la más libre de todas, que mediante la conjunción

${ }^{36}$ Delepierre, Trübner, Londres, 1870, pág. 10. La traducción es mía.

${ }^{37}$ Cf. loc. cit., pág. $8 \mathrm{n}$.

38 Cf. G. Genette, Palimpsestos. La literatura en segundo grado (trad. C. Fernández), Taurus, Madrid, 1989, pág. 23. Delepierre recoge la definición de Escalígero de la edición de Richelet de 1732, pero cuando cita ésta, lo hace de manera indirecta a través del diccionario francés de Littré. Véase Essai sur la parodie, págs. 7-8.

39 Para este autor, el burlesque, la caricatura, el grotesco y la parodia constituyen expresiones distintas, todas ellas al servicio de la sátira.

${ }^{40}$ Cf. loc. cit., págs. 10-11. Una perspectiva totalmente opuesta se lee, en 1915, en la obra de un académico como Francisco de Icaza, quien en El Quijote durante tres siglos (Renacimiento, Sevilla, 1918, pág. 29) asienta: «En el Quijote no hay, en rigor, parodia; no es el héroe puesto en ridículo; no es el propio Rolando o Amadís de Gaula pasando aventuras ridículas con princesas ridículas también». 
paradójica de fingimiento y sinceridad, de burla y seriedad, permite al sujeto ir más allá de sí mismo ${ }^{41}$. En otros sitios, no obstante, desplaza la noción al ámbito de la estética y, en especial, de la literatura, para referirse al incesante distanciamiento irónico del creador para con su obra - condición, opina el filósofo, sine qua non del arte - como «parodia potenciada», donde «la parodia es realmente la potenciación misma [y] la ironía es meramente el equivalente del deber ir al infinito ${ }^{42}$. Es en este distanciamiento infinito, que observa en autores como Shakespeare y Cervantes, donde el menor de los Schlegel sitúa el ingenio de la poesía romántica, una cualidad que viaja de los pequeños detalles a la construcción general de la obra, y que se comprende a la luz de un original que, pese a toda transformación, alumbra el sentido de lo que parece disparatado ${ }^{43}$; esto, a la manera de aquellos experimentos teatrales, populares en su época, «en los cuales a menudo el método y las máximas del procedimiento artístico son más importantes que el resultado» ${ }^{44}$.

Son estos experimentos dramáticos los que, en oposición a Delepierre, permitirán a Gustave Lanson asociar parodia y burlesque. Para Lanson, quien en su artículo «La parodie dramatique au XVIII ${ }^{\mathrm{e}}$ siècle», de 1895, revisa un significativo catálogo de obras teatrales y óperas cómicas, la parodia constituye la «forma dramática del género burlesco» ${ }^{45}$. Depositando su rasgo distintivo en la degradación ridiculizante de los personajes y las acciones imitadas, el francés subraya el carácter progresista y contestatario del drama paródico del siglo XVIII ${ }^{46}$, al que asigna la función de defender el arte libre y realista mediante el señalamiento de los defectos y clichés del teatro oficial, caso de la tragedia clásica y la ópera ${ }^{47}$. En este sentido, señala Sangsue, Lanson se anticipa a la teoría contemporánea, y en especial a los formalistas rusos quienes, un cuarto de siglo más tarde, otorgarán a la parodia un papel protagónico en el marco de la evolución literaria ${ }^{48}$.

\footnotetext{
${ }^{41}$ Lyceum, CVIII.

${ }^{42}$ Citado en las notas de D. Sánchez y A. Rábade a Poesía y filosofía, Alianza, Madrid, 1994, pág. 53

${ }^{43}$ Conversación sobre la poesía (trad. L. Carugati y S. Giron), Biblos, Buenos Aires, 2005, pág. 67.

${ }^{44}$ Loc. cit., pág. 91.

${ }^{45}$ En G. Lanson, Hommes et livres, Oudin, París, 1895, pág. 266. Citado en G. Genette, op. cit., pág. 176. Mías las cursivas.

${ }^{46}$ Lanson liga esta tradición del teatro francés a la feria y a la comedia italiana, muchos de cuyos exponentes triunfaron en Francia durante el siglo XVIII. Se trata de un extenso repertorio travestista que comprende títulos como los Troyennes de Champagne, de Vadé, el Philomèle, de Piron, la Agnès de Chaillot, de Dominique, y el Alceste, de este último y Romagnesi, además de un gran número de Arlequines y Travestis en referencia a personajes como Rolando, Faetón, Belerofonte, Perseo, Edipo... Véase G. Lanson, op. cit., pág. 265 y sigs.

${ }^{47}$ Cf. loc. cit., págs. 271 y 277.

48 Véase D. Sangsue, op. cit., págs. 27-28.
} 


\section{Los formalistas rusos: parodia y evolución literaria}

Los primeros en reparar en las funciones propiamente literarias de la parodia y en situarla en el marco de un modelo de análisis de la literatura fueron, no es un secreto, los formalistas rusos. No de un golpe milagroso sino a lo largo del desarrollo del llamado «método formal», ellos le otorgaron el estatuto del que hoy goza en el ámbito de los estudios literarios. Por cuanto al desarrollo del concepto mismo de parodia en el seno del formalismo, resulta significativo que el famoso ensayo de Víctor Shklovski de 1921, intitulado originalmente «Tristram Shandy de Sterne y la teoría de la novela»"49, haya sido rebautizado, en su Teoría de la prosa, de 1925, como «Una novela paródica. Tristram Shandy de Sterne» ${ }^{50}$. Cierto, en ninguna de las dos versiones Shklovski hace hincapié en el término «parodia» para referirse a los procesos de transformación del material literario mediante los que Sterne edifica su obra; sin embargo, los hechos coincidentes, por una parte, de que el título de 1925 califique de «paródica» la novela de Sterne, donde el término hace referencia a un dispositivo de alienación, de desplazamiento, y de que, por la otra, el texto describa cómo la novela expone sus procedimientos con el objeto de transformar el material, hacen suponer que, para Shklovski, la parodia constituye un dispositivo de transformación que pone al descubierto los procedimientos literarios.

En contraste con sus primeros años, el formalismo de los años veinte estará marcado por la reflexión sobre la evolución literaria. Así, la primera edición del artículo de Shklovski, misma que, más que otra cosa, subraya la denuncia de los procedimientos formales ${ }^{51}$, coincide con la publicación de «Dostoievski y Gogol (una teoría de la parodia)», donde, amén de proponer que en La alquería de Stepanchikovo y sus vecinos Dostoievski parodia la polémica Correspondencia de Gogol, Yuri Tinianov sugiere, como señala su contemporáneo Boris Eichenbaum, «toda una teoría de la imitación como procedimiento estilístico (la estilización paródica) y como manifestación de la sustitución dialéctica que opera entre las escuelas literariasi $\rangle^{52}$. En este estudio, Tinianov sitúa la esencia de la parodia en la mecanización de un procedimiento específico, mecanización que se hace visible sólo cuando el procedimiento mecanizado es conocido, y le asigna una función doble: la mecanización en sí, y la organización del nuevo material al que el viejo procedimiento mecanizado se incorpora ${ }^{53}$.

${ }^{49}$ En L. Lemon and M. Reis (eds.), Russian Formalist Criticism: Four Essays, University of Nebraska Press, Lincoln, 1965, págs. 25-57. De hecho, el título que aparece en la página inicial del artículo es «Tristram Shandy de Sterne. Comentario estilístico».

${ }^{50}$ Véase Theory of Prose (trad. B. Sher), Dalkey Archive, Elmswood Park, 1990, pág. 147 y sigs.

${ }^{51}$ Aunque de manera marginal, en su estudio sobre Rosanov, de ese mismo año, Shklovski expone algunas consideraciones sobre la importancia decisiva del cambio literario. Véase V. Erlich, Russian Formalism: History-Doctrine, Mouton, La Haya, 1980, pág. 93.

52 «La teoría del método formal» en T. Todorov (ed.), Teoría de la literatura de los formalistas rusos (trad. A. M. Nethol), Siglo XXI, México, 2007 (1970), pág. 49.

${ }^{53}$ Cf. M. Rose, op. cit., pág. 119. 
Emplea, asimismo, el concepto 'palabra máscara' para referirse al revestimiento mediante el que el viejo procedimiento adquiere una nueva función al pasar de un plano a otro, toda vez que, para Tinianov, la parodia, como la estilización, consta cuando menos de dos planos, siendo que ésta supone una continuidad entre ambos planos, cuando que «en la parodia la falta de consonancia disloca un plano del otro» ${ }^{54}$. La mecanización y el refuncionamiento que Tinianov percibe en la parodia acusan particular relevancia en el marco de su teoría de la evolución literaria, ya que, para él, todo elemento literario entra simultáneamente en relación con la serie de elementos semejantes pertenecientes a otras obras, a otros sistemas sígnicos e incluso a otras series, y también con los demás elementos de la serie a la que se incorpora ${ }^{55}$, de modo que el cambio literario dependería de estas dos funciones, autónoma y sinónima o, mejor dicho, del traslado de un elemento de una a otra. Dependería, pues, de la nueva función que se asigna al elemento dado, en cuya distinción residiría su cualidad literaria ${ }^{56}$.

En atención al efecto que suscita el refuncionamiento paródico, sin embargo, ni Shklovski ni Tinianov van demasiado lejos. Sin precisar del todo los conceptos en turno, el primero argumenta, en un estudio de 1923 sobre Pushkin y Sterne, que toda obra literaria, paródica o no, puede ser calificada de cómica en una época determinada y de trágica en otra ${ }^{57}$, mientras que, en el marco de su análisis del refuncionamiento cómico de los procedimientos gogolianos efectuado por Dostoievski, el segundo asegura que, si la parodia de una tragedia resulta en una comedia, puede entonces que la parodia de una comedia resulte en una tragedia ${ }^{58}$. A lo más que llega Tinianov es a ver en la parodia una estilización que, o bien obedece a una intención cómica, o simplemente acentúa su propio contraste ${ }^{59}$. En este sentido, la concepción de Boris Tomachevski parece, de buenas a primeras, la más completa. En 1925, este autor recuperará las nociones sobre la puesta al descubierto del viejo procedimiento y su refuncionamiento en el marco de un nuevo material, pero tendrá la certeza de establecer la siguiente distinción: «Si la puesta al desnudo de un procedimiento literario ajeno asume, al realizarse, un valor cómico, tenemos la parodia» ${ }^{60}$. Hasta aquí, todo bien. El malentendido aparece, empero, a continuación, pues inmediatamente después de afirmar que son muchas y muy variadas las funciones de la parodia, Tomachevski las reduce a una sola: ridiculizar la escuela literaria opuesta con el objeto de desenmascararla y destruir así su sistema creador. No para ahí pues, pese a lo dicho, unas líneas más abajo libera a la

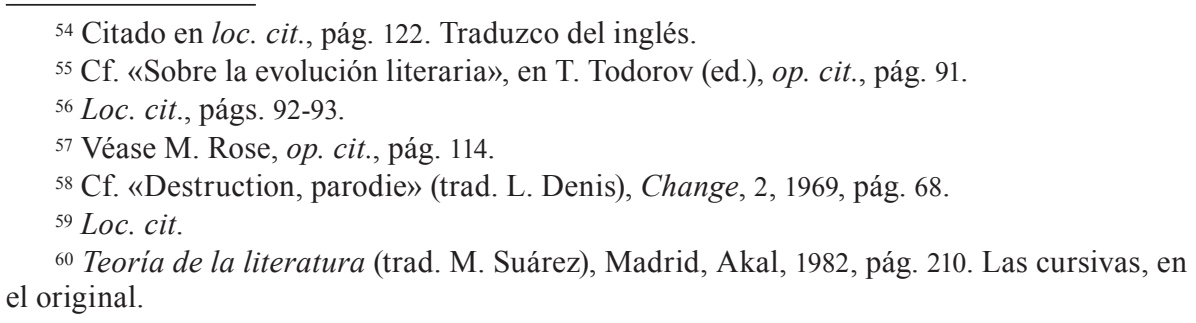


parodia del imperativo satírico y le otorga la posibilidad, que halla en Sterne y sus contemporáneos, de constituirse como «un arte autónomo de la puesta al desnudo del procedimiento» ${ }^{61}$, argumento en el que, muy a su pesar (y de sus colegas), las nociones de puesta al descubierto y refuncionamiento se desligan por completo de la postura formalista a propósito de la evolución literaria. Para terminar, y ahondar en la confusión, el teórico atribuye un efecto cómico a todo procedimiento que se hace perceptible a pesar de los esfuerzos del autor por mantenerlo oculto, con lo que el desnudamiento intencional (estéticamente motivado) se convierte en una suerte de anticipación al efecto jocoso $\mathrm{y}$, por ende, también en su aniquilación.

Con todo, la concepción de la parodia como puesta al descubierto de un procedimiento literario ajeno que, a la luz de su nueva función, asume una valoración cómica o, en pocas palabras, «como refuncionamiento cómico de un procedimiento mecanizado», concuerda, como ninguna otra, con las implicaciones epistemológicas del «método formal», ya que ofrece una valiosa herramienta de identificación para el análisis de las formas y sus mutaciones.

\section{Mijaíl Bajtín: parodia y heteroglosia}

A pesar de que, en términos lingüísticos, Bajtín desplazó el interés de los estudios literarios de la forma a la sustancia, su modelo abunda en coincidencias con los planteamientos de los formalistas. Si éstos «consideraban que toda obra literaria se define en relación con otras obras — señala Daniel Sangsue ${ }^{62}$ Bajtín opina, de manera muy amplia, que ningún enunciado se comprende si no es con referencia a otros enunciados $\rangle^{63}$. En ello radica, en términos generales, el fundamento de su visión dialógica del lenguaje y, por tanto, también de la literatura, y en ello supera, asimismo, a sus predecesores, ya que su teoría literaria va de la mano de una auténtica filosofía del lenguaje en la que, más que una serie autónoma, la literatura constituye una subserie de la tradición que occidente concibe como cultura ${ }^{64}$. Sólo así se comprende que, siguiendo la añeja costumbre de distinguir entre una ironía de corte retórico, poco recomendable, y una segunda clase, diríase, de carácter ético ${ }^{65}$, en su ensayo de 1935 «La palabra en la novela», Bajtín oponga, a una parodia meramente retórica consistente en la «destrucción burda y superficial del lenguaje ajeno», otra

${ }^{61}$ Loc. cit.

62 Véase V. Shklovski, op. cit., pág. 25.

${ }^{63}$ D. Sangsue, op. cit., pág. 37. Mía la traducción.

${ }^{64}$ En esto, Bajtín coincide silenciosamente con Ernst Curtius, cuya perspectiva se basa en una hipótesis semejante (V. Literatura europea y Edad Media latina (trad. M. Frenk y A. Alatorre), Fondo de Cultura Económica, México, 1955, I y II). Por su parte, los formalistas obviaron las antiquísimas filiaciones del procedimiento, en especial las de orden sustancial.

65 Véanse, por ejemplo, Cicerón, De oratore, II 67, 269-70; Castiglione, I libri del cortegiano, II 72, 2-8; F. Schlegel, Lyceum, XLII. 
especie orientada a «recrear el lenguaje parodiado como un todo esencial que posee su lógica interna y que revela el mundo especial ligado de modo inseparable al lenguaje parodiado» ${ }^{66}$, una clase de estilización que, si bien poco se distingue en lo formal del concepto acuñado por Tinianov, reviste ya un carácter sustancial del que deriva su productividad. Y sólo así se comprende, valga la redundancia, que en la parodia contemporánea Bajtín haya detectado únicamente variedades improductivas de la primera clase ${ }^{67}$, negligencia que, a la luz del formalismo, debe ser tachada de reaccionaria ${ }^{68}$.

Precisar la concepción bajtiniana de la parodia es tarea complicada porque la palabra aparece de continuo en su obra situándose siempre, las más de las veces de modo implícito, en un punto de la extensa línea que separa una acepción categórica de la otra. Incluso así, empero, contemplando el periodo transcurrido entre la aparición, en 1929, de sus Problemas de la obra de Dostoievski y la publicación de los Problemas de la poética de Dostoievski, en 1963, resulta plausible considerar concluyente, en la segunda obra, la definición de la parodia como «el empleo de la palabra ajena con una orientación de sentido completamente opuesta»: «La segunda voz, al anidar en la palabra ajena, entra en hostilidades con su dueño primitivo y lo obliga a servir a propósitos totalmente opuestos. La palabra llega a ser arena de lucha entre dos voces» ${ }^{69}$. Salta a la vista el paralelismo entre esta definición y la de Tomachevski, más aún porque Bajtín incurre, casi con las mismas palabras, en una contradicción análoga a la de su predecesor al sugerir a continuación que el estilo ajeno es susceptible de ser parodiado en diversos sentidos y con diferentes acentos ${ }^{70}$, a menos, y en ello cabe reconocer la plusvalía de su definición, que por «completamente opuestos» se entienda, por ejemplo, la oposición entre tragedia y comedia, entre alto y bajo, joven y viejo, llano y rebuscado... ${ }^{71}$ A esta lectura se suma que, más que «significado», el teórico emplea los términos «orientación de sentido» (смысловая направленность) у «propósitos» (цели) ${ }^{72}$.

${ }^{66}$ M. Bajtín, Problemas literarios y estéticos (trad. A. Caballero), Arte y Literatura, La Habana, 1986, pág. 203. En un sentido formal, tampoco su distinción entre la simple estilización y la estilización paródica difiere de la de Tinianov. Véase M. Bajtín, loc. cit., páginas 201-202.

${ }^{67}$ Véase M. Bajtín, La cultura popular en la Edad Media y en el Renacimiento, pág. 16.

${ }^{68}$ Cierto, como señalan Katerina Clark y Michael Holquist (Mikhail Bakhtin, Harvard University Press, Cambridge y Londres, 1984, pág. 269), Bajtín comparte la predilección por los autores del llamado humorismo inglés (Sterne, Dickens, Fielding...) con los formalistas; no obstante, mientras que, a propósito de la parodia, éstos ven en Sterne y sus contemporáneos un momento revolucionario en el marco de la evolución literaria, en cierto sentido Bajtín los considera un límite histórico, la última posibilidad de la empresa iniciada por Rabelais y Cervantes, su reducción definitiva.

${ }^{69}$ Trad. T. Bubnova, Fondo de Cultura Económica, México, 2003, pág. 282.

${ }^{70}$ Loc. cit.

${ }^{71}$ M. Bajtín, «De la prehistoria de la palabra de la novela», en Problemas literarios y estéticos, pág. 505.

72 Véase Aristóteles, Categorías, IX y X, 11b-13b. 
Sin embargo, pese a lo concluyente de la definición anterior, se halla en Bajtín una segunda serie de ideas sobre la parodia cuyo eje temporal va de la colección de ensayos de poética histórica Las formas del tiempo y del cronotopo en la novela, en particular del artículo dedicado a Rabelais ${ }^{73}$, escrito entre 1937 y 1938, a la publicación, en 1965, de su estudio sobre el contexto rabelaisiano. En este último, por ejemplo, en el que concibe la cultura popular de la baja edad media y el renacimiento como una parodia de la vida oficial ${ }^{74}$, se lee:

El pensamiento y la palabra buscaban la realidad nueva más allá del horizonte aparente de la concepción dominante. Y, a menudo, palabras y pensamientos se retorcían adrede para ver qué había realmente detrás de ellos, qué había en el revés. Buscaban la posición a partir de la cual pudiesen ver la otra ribera de las formas de pensamiento y de los juicios dominantes, a partir de la cual pudiesen lanzar nuevas miradas sobre el mundo ${ }^{75}$.

Donde reducir ambas riberas «de las formas de pensamiento y de los juicios dominantes» a una oposición radical, y las «nuevas miradas sobre el mundo» a la sustancia de dicha oposición, equivale a olvidar que las riberas comparten un río o un mar y que, alimentándolas a ambas, ese caudal, ese océano (ese mundo), no pertenece a ninguna de las dos.

\section{Un paréntesis: Yuri Lotman}

A diferencia de Bajtín e, incluso, de los formalistas, la teoría literaria de Lotman no abunda en referencias a la parodia. Tal vez sea por ello que sus postulados al respecto han encontrado escaso eco en otros sistemas de pensamiento. Aun así, es sabido que, en su peculiar modelo estructuralista, Lotman incorpora elementos tanto del de Orel como de los miembros de la Opoiaz. Su concepción dialógica de la conciencia y, en sentido más amplio, de la cultu$\mathrm{ra}^{76}$, posee muchos puntos en común con la de Bajtín, si bien se diferencia de ella en que desplaza el foco de atención del mensaje (el texto, para Lotman) a la interrelación dialéctica del emisor y el receptor. En lo que respecta a la literatura, esto quiere decir que el texto es en sí monológico, eminentemente informativo, y sólo se vuelve dialógico cuando la interrelación autor-lector excede el carácter meramente informativo, o sea, cuando el texto se crea o se percibe sobre el fondo de otras series sígnicas. A menos que el texto muestre

${ }^{73}$ Véase Problemas literarios y estéticos, págs. 362-431.

${ }^{74}$ Véase La cultura popular en la Edad Media y en el Renacimiento, pág. 16

${ }^{75}$ Loc. cit., pág. 244.

${ }^{76}$ La primera la explica el autor en su artículo de 1981 «El texto en el texto» (en La semiósfera (trad. y comp. D. Navarro), Cátedra/Universitat de València, Madrid y Valencia, 1996, I, págs. 91-109), mientras que la segunda se lee implícitamente en la perspectiva semiológica que priva en su obra. 
de manera consciente un principio de autodestrucción, las categorías que, en su poética de $1970^{77}$, el semiólogo de Tartu denomina «estética de la identidad» y «estética de la oposición» están sujetas inevitablemente a la tensión que el texto suscita entre autor y lector.

Las repercusiones de este modelo en el análisis de textos que comprenden su propio principio de oposición, caso de la parodia, conducen a Lotman a recuperar el «procedimiento mecanizado» de los formalistas y a rebautizarlo como «cliché estructural», pero sólo para concluir que, en la parodia, su destrucción no supone su reemplazo por una nueva estructura textual (el refuncionamiento, para aquéllos), sino que esta nueva estructura la provee el lector a la luz de su competencia retórica, es decir, a la luz del complejo de series sígnicas que comprenden su repertorio y que le permiten recodificar el texto. Según esto, la plena percepción de la parodia depende del conocimiento, previo a la lectura del texto paródico, de otros textos que, tras destruir la estética del cliché, la han reemplazado por una visión más convincente en los términos del propio texto: «solamente la existencia en la conciencia del lector de una estructura de este tipo, nueva, le permite completar el texto destructivo de la parodia con un elemento constructivo extratextual $\rangle^{78}$, existencia que, vista de este modo, pone en entredicho el papel protagónico que los formalistas atribuyeron a la parodia en la esfera de la evolución literaria. Pienso, por ejemplo, en el Quijote de 1605. $\mathrm{Su}$ estructura narrativa, cierto, no es novedosa; de hecho, es la misma que se halla, en particular, en el romance caballeresco, aunque también, de manera general, en la novela de aventuras. Con respecto a los libros de caballería son pocos los rasgos estructurales que marcan la diferencia; el recurso del autor que presenta la obra de otro autor a propósito de una historia tal no lo inventó Cervantes, mientras que la función especular que se asigna a dicho recurso al principio de la novela y en ciertos momentos posteriores no se manifiesta del todo como una lectura en abismo. A cambio, la cualidad diferencial de la obra cervantina - para los formalistas, lo verdaderamente literario de ellase mide sobre el fondo, se me ocurre, de la novela ejemplar y la picaresca, ambas en auge a la sazón del medio literario español. Cabe entonces coincidir con Lotman en que, en lo estructural, la parodia no resulta necesariamente productiva.

No puede, sin embargo, decirse lo mismo en sentido genérico, más aún convieniendo con Jonathan Culler en que las convenciones de esta clase suelen permanecer inexpresadas ${ }^{79}$. En cualquier caso, más que en los elementos visibles del texto, en su estructura, la transformación paródica se manifiesta en un estrato infraestructural del texto, en ese sobreentendido que, bien señala Lotman, toda parodia expresa negativamente, no en balde dice Bajtín que, si sólo la lengua

77 Cf. Estructura del texto artístico (trad. V. Imbert), Istmo, Madrid, 1988, págs. 345-357.

${ }^{78}$ Loc. cit., pág. 354

${ }^{79}$ La poética estructuralista. El estructuralismo, la lingüistica y el estudio de la literatura (trad. C. Manzano), Anagrama, Barcelona, 1978, pág. 208. 
parodiada está presente en el texto paródico, «la otra, en cambio, lo está invisiblemente, como el fondo activo de la creación y la percepción ${ }^{80}$. Tratándose de Cervantes, este sedimento activo, imperceptible a la luz del texto, constituye el legado que posibilitará la aparición de la novela moderna, cuyas convenciones genéricas, resta decirlo, admiten prácticamente cualquier estructura.

\section{La escuela de Francia: parodia e intertexto}

Fuera de Rusia, la teoría literaria francesa fue la primera en acoger el complejo ideológico de Bajtín y, en particular, sus consideraciones acerca de la heteroglosia. En su seno, estas consideraciones habrían de conducir al concepto, hoy tan conocido, y tañido, de «intertextualidad» ${ }^{81}$. La primera teoría de la parodia elaborada sobre la base de este concepto se debe, creo, a Claude Bouché, cuyo análisis de Lautréamont, de 1974, contempla prácticamente toda la problemática que ocupará, en adelante, a los estudios literarios sobre el fenómeno.

Más que en su definición de la parodia como «refuncionamiento caricaturesco del referente $\rangle^{82}$, en callada coincidencia con la de los formalistas, la novedad de su teoría estriba en que le permite a Bouché desarrollar un «método intertextual» ${ }^{83}$ a partir del que distingue cinco clases de intertextos, según la función citatoria que se asigna a él o los textos anteriores en su paso al texto nuevo ${ }^{84}$. En este marco llama plagio o, en su caso, collage al texto que «reproduce» un pre-texto único, y pastiche al texto que «imita» un pre-texto único o un conjunto de pre-textos de un solo autor; el texto que «fabrica» un ensamble de pre-textos posibles constituye, según esto, un estereotipo, mientras que la alusión correspondería al texto que «reenvía» a un conjunto de pre-textos o bien a un contexto dado. Finalmente, aunque no en este orden, la parodia figura como el texto que «caricaturiza» un pre-texto único, un conjunto de pre-textos

80 «De la prehistoria de la palabra en la novela», pág. 504.

81 Acuñado en 1967 por Julia Kristeva en su artículo «Bakhtine, le mot, le dialogue et le roman» (véase «Bajtín, la palabra, el diálogo y la novela», en D. Navarro [comp. y trad.], Intertextualité. Francia en el origen de un término y el desarrollo de un concepto, UNEAC/Casa de las Américas, La Habana, 1997, pág. 3), parte de la hipótesis bajtiniana de que todo enunciado literario se realiza como un diálogo entre el sujeto de la enunciación y los referentes y destinatarios que conforman el contexto. La posibilidad, señalada por Bajtín, de establecer relaciones referenciales entre un texto y otro condujo a la cabal comprensión del concepto de alusión, pieza clave de teorías polifónicas posteriores, como las de Ducrot, Genette y Barthes. Véase H. Beristáin, Alusión, referencialidad, intertextualidad, Universidad Nacional Autónoma de México, 1996, págs. 26-39.

82 Cf. Lautréamont. Du lieu commun a la parodie, Larousse, París, 1974, págs. 39, 43.

${ }^{83}$ Loc. cit., pág. 32.

${ }^{84}$ Caracterización que, por ejemplo, se ofrece más completa que aquella otra desarrollada por Gonzalo Navajas en Mímesis y cultura en la ficción. Teoría de la novela (Tamesis, Londres, 1985, págs. 74-82). 
de un solo autor o bien un género, una escuela o corriente de pensamiento ${ }^{85}$. Desde luego que semejante taxonomía dista mucho de agotar el catálogo de textos que refieren a otros textos. Dónde quedan, me pregunto, los textos que reenvían a un texto único, como, se me ocurre, La ciudad ausente, de Ricardo Piglia, con su evocación del Museo de la novela de la Eterna, de Macedonio Fernández; dónde el itálico modo, hecho a imitación de una escuela poética. ¿En el pastiche, en el plagio? Tampoco agota, cabe añadir, el conjunto de relaciones y correlaciones que pueden darse entre un texto y las fuentes sobre las que se construye. ¿Qué clase de refuncionamiento es el que realizan los Seis personajes en busca de autor, de Pirandello, con respecto a, digamos, la comedia del arte, o Jacques y su amo, de Kundera, en relación con la novela de Diderot? ¿Caricatura de la caricatura, fabricación..., reenvío? Resulta evidente, por otra parte, el paralelismo de lo que Bouché nombra «imitación de estilo», de donde el pastiche, con lo que los formalistas y Bajtín llamaron simplemente «estilización», si bien este último término parece más adecuado para hablar, pienso, de la poesía neoclásica. La mayor inconsistencia de este aparato teórico estriba, no obstante, en que, sin darse cuenta de que tan sólo la «fabricación» supone ya un refuncionamiento sustancial (el estereotipo reviste tal carácter), reduce conscientemente el espacio intertextual, tal como hicieron los formalistas, al aspecto formal de la repetición, deformadora tratándose de la parodia, con lo que ésta, como en Tomachevski, queda eximida del imperativo satírico ${ }^{86}$.

Al margen de estas sutilezas, el modelo de Bouché ofrece, primero, una ventaja metodológica insoslayable al precisar el campo de acción de la parodia, que puede ir de un único texto a una corriente de pensamiento ${ }^{87}$, y tipificar correctamente los procedimientos específicos de transformación que todo texto paródico pone en marcha con respecto a sus fuentes, y en segundo lugar, un

${ }^{85}$ Cf. C. Bouché, op. cit., págs. 40-48.

${ }^{86}$ Cf. loc. cit., págs. 37-38.

${ }^{87}$ Nótese que el autor, al referirse a las corrientes de pensamiento como posibles blancos de la parodia, sin percatarse de ello, menciona implícitamente asuntos de carácter sustancial. Parece improbable, si no es que imposible, establecer filiaciones intertextuales de orden estrictamente formal entre un texto y un objeto que no es de hecho ni un texto ni un conjunto de textos, es decir, que no tiene la forma de texto. El nominalismo, $v$. gr., no conforma ni un estilo ni una retórica, sino un conjunto de ideas expresadas mediante una infinidad de estilos y retóricas. Sería insensato, por donde se vea, considerar que Locke, Nietzsche y Paz comparten el estilo o la retórica de San Agustín, cuando está claro que cada uno de ellos expresa sus pensamientos mediante una textualidad distinta. El espacio intertextual entre un texto como Tristram Shandy y una corriente de pensamiento como el nominalismo, que de hecho lo hay, posee un carácter sustancial, lo que no quita que Sterne pueda parodiar también, no sé si lo haga, el estilo de Locke o la retórica de San Agustín. El propio Bouché, cuando se refiere a la duplicidad intertextual (paródica) de los Cantos y las Poesías de Ducasse, no puede evitar hacer uso de términos como «discurso», «ideología burguesa», «cultura oficial», o de una sentencia como «la parodia incluye en su propia sustancia los textos y los discursos que transforma», y tampoco puede, asimismo, dejar de notar que esta inclusión desempeña una función negativa (cf. op. cit., págs. 187-195), con todo y que, con anterioridad, había liberado a la parodia del poder de sanción con respecto a toda «realidad extratextual». 
postulado teórico de gran valía que, curiosamente, no contemplan como tal los demás autores que conozco en la materia, y que consiste en atribuir a la parodia la función, incuestionable para mí, de reflexionar sobre la problemática de la escritura, sobre el acto mismo de escribiris

En su Palimpsestes, de 1982, Genette sigue una estrategia análoga a la de Bouché, aunque, estructuralmente hablando, doble, pues donde éste observa, entre el texto y su(s) modelo(s), una clase de relación funcional, Genette identifica dos factores distintos: por un lado, la clase de relación y, por otro, la función que ésta desempeña en el nuevo contexto. Esto le permite hablar de dos tipos de relación, según si se trata de una imitación o bien de una transformación y, de entrada, de dos funciones primordiales: satírica y no satírica. Sobre esta base, Genette caracteriza la parodia como resultado de un mínimo de transformación, y el travestimiento como la transformación que obedece a una función satírica; en contraparte, denomina «charge» a la imitación con función satírica y pastiche a la emulación no satírica. Resulta de ello un cuadro sinóptico en el que las relaciones de transformación, según si desempeñan o no una función degradante, conducen respectivamente al travestimiento y la parodia, mientras que las de imitación desembocan en la imitación satírica y en el pastiche ${ }^{89}$.

A diferencia de lo que ocurre en Bouché y Tinianov, donde se debe a una confusión, en Genette la separación categórica de sátira y parodia obedece a un error consciente. Él mismo reconoce que la definición tradicional de «parodia», que rastrea hasta la antigüedad, comprende una función satírica que figura aun en los modelos en que se la sustituye, así en Bouché, por términos como «burla» $\mathrm{o}$ «caricatura» 90 , y al mismo tiempo es consciente de que, al liberar a la parodia de su carga satírica y dotarla de un carácter estrictamente lúdico, la exime asimismo de toda dependencia con respecto al texto base, al que, asegura, no «toma por objeto de un tratamiento estilístico comprometedor, sino sólo como modelo o patrón para la construcción de un nuevo texto que, una vez producido, ya no le concierne» ${ }^{91}$. No puedo, en este punto, estar más en desacuerdo con Genette y menos en conformidad con Lotman a propósito de la dependencia, cuando menos estructural, que todo texto paródico observa con respecto a su modelo. Me pregunto dónde se sitúa, en el cuadro del francés, un texto como El banquete de los eruditos, que toma como base el modelo clásico del simposio pero se compromete a perfeccionarlo en lo que toca al estilo y la composición ${ }^{92}$. No se trata de un travestimiento, puesto que representa personajes

${ }^{88}$ Cf., loc. cit., pág. 182 y sigs.

${ }^{89}$ G. Genette, op. cit., págs. 37-40.

${ }^{90}$ Cf., loc. cit., págs. 32 y 35 .

${ }^{91}$ Loc. cit., págs. 39-40. En apego a una añeja tradición, un clasicista como Cèbe contempla dos categorías de parodias: las satíricas y las placenteras; a ambas, no obstante, las exenta de un verdadero compromiso de transformación, ya que, para él, y en oposición a la caricatura, a la que otorga el carácter de representación, la parodia no pasa de ser una imitación, una copia deformada. Véase $o p$. cit., págs. 8-11.

92 Véase Ateneo, V 182a, 186e, 187a y sigs., 192d-217d. 
y trata temas distintos, y no contrarios, de los que aparecen, por ejemplo, en Platón y Jenofonte, de ahí que tampoco se lo pueda ver como pastiche, toda vez que de la imitación pasa a la transformación. Lo cierto es que, con referencia a sus modelos, comporta a la vez un carácter paródico, de transformación, y uno satírico, de crítica y perfeccionamiento ${ }^{93}$. Como puede verse, este primer cuadro estructural dista mucho de resultar extensivo, de ahí que, en adelante, el padre de la narratología se vea obligado, primero, a distinguir dos clases de función - que ahora recibe el nombre de régimen - en el ámbito de lo no satírico: la lúdica, en la que entrarían la parodia y el pastiche, y la seria, donde la transformación da lugar a una transposición y la simple estilización conduce a la imitación seria («forgerie»), y luego a intercalar tres subespecies entre los regímenes resultantes: entre el lúdico y el satírico, el irónico; entre el satírico y el serio, el polémico, y entre el serio y el lúdico, el humorístico ${ }^{94}$. Si bien el cuadro sinóptico que Genette desarrolla a partir de semejante taxonomía, $\mathrm{y}$ en el que la parodia figura como «transformación lúdica del modelo», posee virtudes incuestionables, me parece que conduce a una serie de interferencias genéricas que no hacen sino oscurecer la cuestión (caso de lo que denomina «parodia mixta» ${ }^{95}$, que correspondería a una transformación del personaje en la que opera una mezcla de los estilos alto y bajo, noble y vulgar, como en las parodias dramáticas a las que se refiere Lanson, y también de la llamada antinovela ${ }^{96}$, categoría en la que incluye el Quijote de Cervantes, Le Berguer extravagant (1627), de Sorel, y el Télémaque travesti (1736), de Marivaux, todas ellas sobre personajes que adoptan personalidades ajenas).

Así, el modelo de Genette servirá de plataforma para que, dos décadas después, Daniel Sangsue proponga su definición «operativa», ¿o restrictiva?, de la parodia como «transformación lúdica, cómica o satírica de un texto singular» ${ }^{97}$, definición que, amén de no precisar diferencias positivas entre los regímenes, en especial entre el lúdico y el cómico, poco tiene de operativa desde que, como señala el autor unas líneas más adelante, las fronteras que separan unos de otros resultan muchas veces imposibles de discernir (ahí están los casos, contemplados por el teórico, del Doctor Fausto [1947], de Thomas Mann, y el Cassanova [1918], de Apollinaire), a lo que se agrega el subtexto casi

${ }_{93}$ De hecho, el Banquete de los eruditos también pone en tela de juicio la suposición genettiana (véase op. cit., pág. 29) de que la parodia suele ejercer sobre textos breves, las más de las veces, extraídos de su contexto natural (nótese la oposición con Bajtín). Ateneo, por el contrario, produce una obra monumental que, por tratar precisamente sobre el género del banquete, comprende a sus predecesores, algunas de cuyas obras no son lo que se dice breves (ahí están las Charlas de sobremesa, de Plutarco), en el contexto que les corresponde. Otro tanto debe decirse de la Batracomiomaquia que, si bien recrea el complejo homérico en unos cuantos versos, lo contempla como una totalidad orgánica desde el punto de vista así estructural como temático.

${ }^{94}$ Op. cit., $40-44$.

${ }_{95}$ Cf. loc. cit., págs. 175-182.

${ }^{96}$ Cf. G. Genette, op. cit., págs. 182-195.

${ }^{97}$ Op. cit., págs. 73-74. Las cursivas son mías. 
explícito de que una parodia completa ha de reunir cualidades tanto lúdicas como cómicas y satíricas ${ }^{8}$. Por otra parte, la reducción del campo de acción de la parodia a un texto único descarta un extenso catálogo de textos considerados paródicos, no ya por teóricos y críticos, por el público en general. Más aún, su tendencia reductiva llevará a Sangsue a constreñir la intertextualidad, tal como Bouché, a un espacio entre textos en el que sólo entra en juego lo «literario», lo formal ${ }^{99}$.

En este sentido, la restricción de Sangsue representa un paso atrás con respecto a Genette, para quien un simple desvío de sentido, o bien del contexto y la dignidad, es suficiente para hacer de la cita más breve una parodia ${ }^{100}$. Si la llamada nueva crítica francesa no se comprende sino sobre el fondo de la filosofía lingüística de Bajtín, me parece incuestionable que, de manera general, el que con mayor apego hace honor a su maestro es, justamente, Genette, más allá de que, a diferencia de otros exponentes de la escuela, en su obra no abundan las referencias directas al teórico ruso. A pesar de ello, ahí donde Bajtín pinta un universo referencial: la heteroglosia, el plurilingüismo, del que la estilización, incluso la parodia, constituye solamente una parte, el francés observa un espacio architextual donde los intertextos, es decir, las relaciones de orden estrictamente formal entre textos, interactúan con otras operaciones architextuales que incorporan procedimientos de carácter sustancial ${ }^{101}$.

\section{La crítica anglosajona: parodia y metaficción}

Los modelos de Bajtín y Genette ofrecen, ambos, la posibilidad de establecer nexos de corte paródico entre textos y/u otros objetos, ventaja de la que no se exenta el formalismo pues, para Tomachevski, la diferenciación de los procedimientos literarios:

[...] es natural cuando proviene de alguna afinidad interior que les permite combinarse fácilmente [...] literaria y social cuando deriva de los objetivos propuestos a las obras particulares, de las circunstancias de su creación, de su destinatario, de la acogida que se le dispensa [...] histórica cuando procede de la imitación de obras antiguas y de las tradiciones literarias ${ }^{102}$.

\footnotetext{
${ }_{98}$ Cf. loc. cit., pág. 74.

${ }^{99}$ Cf. loc. cit., pág. 54.

100 Op. cit., pág. 27.

${ }^{101}$ Véanse op. cit., págs. 9-20 y, para una comprensión cabal, Introduction a l'architexte, Seuil, París, 1979.

102 «Temática», en T. Todorov (ed.), Teoría de la literatura de los formalistas rusos, pág. 228. Sigo aquí la traducción de Ana María Nethol, y no la de Marcial Suárez (véase Teoría de la literatura, pág. 211), porque me parece que enfatiza la naturaleza de la diferenciación y no tanto su origen.
} 
De ahí que la deuda que, al respecto de la parodia, el formalismo reclama a la teoría anglosajona del siglo XX no reciba justo pago, pues ésta, lo mismo que una parte de la crítica francesa, ha circunscrito la parodia a las operaciones formales entre textos. Así, en su Parody/Meta-Fiction, de 1979, Margaret Rose caracteriza la parodia como «citación crítica de un lenguaje literario con efecto cómico» $103 \mathrm{e}$, intentando distinguirla de «otras formas de sátira», asegura que, a diferencia de éstas, aquélla incorpora al texto el objeto de su ataque, de donde su capacidad para desenmascarar satíricamente a los escritores emulados mediante el empleo irónico de sus palabras ${ }^{104}$. En lo tocante a la parodia no parece haber, a simple vista, confusión alguna, aunque, por lo que respecta a las «otras formas de sátira», me pregunto de qué modo puede un texto dirigirse contra un objeto sin hacerlo parte de sí cuando menos implícitamente. Puede que Rose también se lo haya preguntado, pues una década y media después, en su libro Parody: Ancient, Modern, and Post-Modern, acotará su distinción para hablar de la parodia, en específico, como «la incorporación a la estructura de un texto nuevo, por medio de citas, imitaciones o distorsiones, de cierto material artístico o literario preexistente», restricción de la que, en adenda, la sátira queda excluida ${ }^{105}$. Sin embargo, aun cuando aquí la parodia no constituye ya, como en su primer trabajo, una forma de la sátira, sino que una y otra parecen capaces de interactuar, lo cierto es que, de la amplia gama de ejemplos que emplea en ambos libros, resulta imposible extraer uno solo en que la autora deje de identificar la velación de un objeto de ataque, sea éste de carácter literario o social, histórico, ideológico, cultural... La dependencia estructural de la parodia con respecto a sus fuentes ya la hizo notar Lotman, pero de ahí a desligar dicha dependencia del imperativo crítico de la motivación, como pretende Rose, dista un largo y arriesgado trecho.

Independientemente de que aporta la, ésta sí, operativa distinción entre una clase de «specific parody», entendida como técnica discursiva de citación ambivalente, y otra más general a la que aquélla se agrega para señalar la dependencia estructural, y ambivalente, de un texto con respecto a otros ${ }^{106}$, el verdadero interés de Rose, no ya en las definiciones, que considera parciales debido a los factores históricos, sociales y lingüísticos que condicionan su acuñación ${ }^{107}$, está puesto, de una parte, en el rescate del efecto cómico que según los antiguos acompaña a la parodia ${ }^{108}$ y que a partir del formalismo palidece a ojos de los especialistas, y de la otra, en subrayar el papel protagónico que los integrantes de la Opoiaz adjudicaron a la parodia en el horizonte de

${ }^{103}$ Croom Helm, Londres, 1979, pág. 59. La traducción y las cursivas son mías.

${ }^{104}$ Loc. cit., pág. 34.

${ }_{105}$ Cf. págs. $81-82$.

${ }^{106}$ Cf. Parody/Meta-Fiction, págs. 33-35, y Parody: Ancient, Modern, and Post-Modern, págs. 47-53.

107 Véase Parody/Meta-Fiction, pág. 17.

${ }^{108}$ Cf. loc. cit., págs. 19-21, y Parody: Ancient, Modern, and Post-Modern, págs. 20-36. 
transformaciones de la tradición literaria ${ }^{109}$. En esta función evolutiva de la parodia estará de acuerdo su contemporánea Linda Hutcheon, más no así en lo que respecta a la coloración cómica que, según Rose, pinta toda transformación paródica.

Remontándose a los orígenes del término, en A Theory of Parody, de 1985, Hutcheon tratará de reivindicar una concepción de la parodia, que lee en los formalistas, en la que el efecto cómico o burlesco no supone un componente esencial ${ }^{110}$, postura que ejemplifica con obras como La amante del teniente francés, de Fowles, y Ulises, de Joyce, en las que observa un tratamiento de las fuentes en tono serio y aun reverente ${ }^{111}$. Renuente, como Rose, a dar crédito a toda definición transhistórica de la parodia, Hutcheon la explica como un «integrated structural modeling process of revising, replaying, inverting, and "trans-contextualizing" previous works of art» $112 \mathrm{o}$, en pocas palabras, como «repetición con una distancia crítica»113. El motivo principal para extraer del complejo el elemento cómico estriba en que, perpetrando la tradición, la autora lo considera enteramente destructivo, cuando que ella defiende la posibilidad de una reconstrucción del material ${ }^{114}$. Al calificar de «constructiva» una clase de crítica totalmente desprovista de agresividad, la canadiense olvida que, como bien recuerda Harold Bloom, «toda lectura crítica que aspire a ser fuerte "debe" ser tan transgresiva como agresiva»"15, imperativo que, es curioso, la propia Hutcheon parece recordar cuando se refiere a la «paradoja» de la parodia, o sea, a su capacidad para trasgredir las normas literarias de manera convencionalmente autorizada ${ }^{116}$.

En este modelo, la ironía figura como el mecanismo retórico que activa la conciencia del lector y posibilita la recepción de los mensajes en clave paródica; esto, al grado de que la autora llega a hablar de «critical ironic distance» para referirse a la actitud del texto paródico respecto a sus fuentes ${ }^{117}$. No puedo, así, a primera vista, más que confirmar esta estrategia ${ }^{118}$, si bien cuando se la sitúa en su respectivo marco teórico las inconsistencias salen a la luz, ya que, al sustituir los conceptos clásicos de burla e irrisión por el término 'ironía',

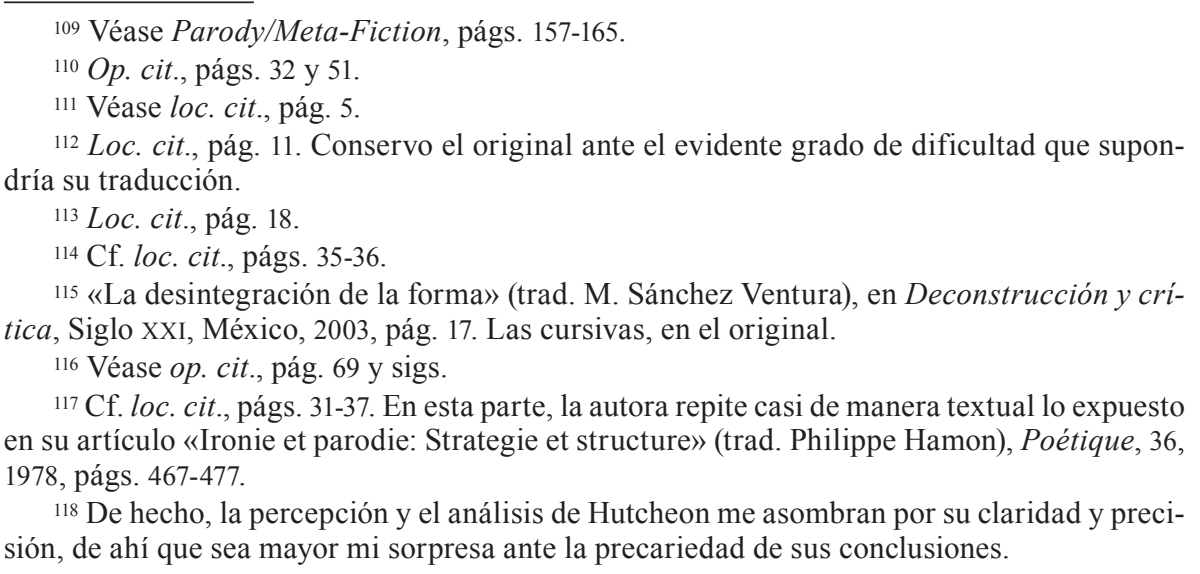


éste queda tan vacío de sentido que la autora se ve obligada, como en el caso de la parodia, a refugiarse en el último reducto etimológico del término, encerrado, opina, en la dualidad disimulación-interrogación ${ }^{119}$. Ahora bien, si en el artículo de 1978 no consigue establecer una diferencia positiva entre parodia e ironía, tres años más tarde ${ }^{120}$, Hutcheon tratará de remediar la falla adjudicando una naturaleza intertextual a la primera e intratextual a la segunda, y echará mano de lo que el grupo de Lieja llamó «ethos», es decir, un estado afectivo suscitado en el receptor de un mensaje y condicionado por una serie de parámetros ${ }^{121}$, para distinguir cualitativamente la ironía de la parodia y ésta de la sátira, en la que, por cierto, detecta un ethos extratextual ${ }^{122}$.

Más allá de la inconveniencia, ya señalada, de semejante distinción, resulta inadmisible que, asignando a la sátira el poder de juzgar negativamente el objeto de su referencia, Hutcheon descarte el contraste como una de sus cualidades. No para ahí pues, pese a que desde su primer artículo supone haber liberado a la parodia de una evaluación crítica enteramente negativa, en su libro de 1985 reconoce que la destructividad de la sátira comprende también un «idealismo implícito» de carácter, no ya constructivo, sino didáctico y comprometido ${ }^{123}$. Así como el recorte del espacio intertextual a lo estrictamente «literario» obedece a una mala lectura de los formalistas por parte de algunos teóricos franceses, la reducción de la función extratextual de la sátira a los ámbitos de lo social y lo moral la hereda Hutcheon de la pésima interpretación por parte de Nortroph Frye de la función correctiva propia de la sátira, que supone conducida por una claridad de las normas morales del autor ${ }^{124}$. Hutcheon parte, y esto sí es novedad, de la caracterización de la ironía como tropo semántico-pragmático, donde lo primero se refiere a la cualidad diferencial del significado y lo segundo a la evaluación negativa del referente ${ }^{125}$, para asociar el aspecto semántico de la ironía con los procedimientos retóricos de la parodia, y su aspecto pragmático con las operaciones sustanciales de

119 Véase op. cit., pág. 53.

${ }^{120} \mathrm{Cf}$. «Ironie, satire, parodie. Une approache pragmatique de l'ironie», Poétique, 46, 1981, págs. 141-155.

121 Véase Grupo $\mu$, Rhétorique générale, Larousse, París, 1970, pág. 147.

${ }_{122} \mathrm{Me}$ parece significativa la consonancia con los presupuestos de Bouché, en particular porque, empleando exactamente los mismos términos, salvo por el ethos, la canadiense omite toda referencia al respecto. ¿Se trata, acaso, de una coincidencia? Tal vez sea para resolver esta anomalía que en su libro de 1985 abandona el término «extratextual» para referirse a la sátira y lo sustituye por «extramuros». Véase op. cit., pág. 25.

${ }^{123}$ Cf. loc. cit., pág. 56.

${ }^{124}$ Cf. Anatomy of Criticism. Four Essays, Princeton University Press, Nueva Jersey, 1957, pág. 223. Asimismo, Frye también cae en el error de observar en la parodia características estrictamente formales (loc. cit., págs. 233-234 y 322), pero se salva de la separación radical que priva en autores como Genette y, de manera más moderada, en Hutcheon, toda vez que subordina la parodia a las operaciones formales propias de la sátira. Véase N. Frye, loc. cit., pág. 322 .

${ }^{125}$ Cf. C. Kerbrat-Orecchioni, «La ironie comme trope», Poétique, 41, 1980, págs. 108-127. 
la sátira, de donde configura un esquema en el que los respectivos ethos de estas tres entidades se relacionan y correlacionan del siguiente modo ${ }^{126}$ : (a) por determinación: la cualidad diferencial del significado irónico determina la «distancia crítica» de la parodia, así como el juicio negativo de la sátira es determinado por la devaluación del referente irónico, y (b) por constelación, en caso de que la parodia satirice un objeto extratextual (social o moral) o bien de que la sátira emplee la parodia como plataforma retórica ${ }^{127}$. Aparte de lo dicho, ninguna interdependencia o, de otro modo, ninguna definición verdaderamente operativa, defecto que, sobra aclarar, proviene de la exigencia de «ampliar el concepto de parodia para hacerlo caber en las necesidades del arte de nuestro tiempo»128.

De modo simultáneo, en 1985, Walter Nash distinguirá la parodia como una alusión controlada, entendida ésta como una clase de citación cuya función excede el carácter decorativo de un intercambio conversacional dado, «una especie de desafío que prueba las credenciales de los iniciados y discrimina a los ignorantes. Se trata de un instrumento de poder que le permite al hablante controlar una situación, poniéndola a su favor» ${ }^{129}$. En unas cuantas líneas, Nash otorga a la parodia la facultad de subvertir a su modelo así en lo estilístico como en lo lógico, postulado que, dicho sea de paso, comparte con Bajtín, pero además le retribuye el efecto cómico del que Hutcheon quizo despojarla ${ }^{130}$. La parodia se muestra, para Nash, tanto en las desproporciones de la expresión misma como en las discordancias entre expresión y contenido, y de ello deriva el efecto cómico que percibe el lector ${ }^{131}$. Por otra parte, aunque en estrecha relación con esto último, el concepto 'alusión controlada' acuñado por el británico encaja bastante bien con el binomio 'mención ecoica' desarrollado por Dan Sperber y Deirdre Wilson a propósito de la ironía ${ }^{132}$, siempre y cuando la que hay entre la alusión y lo aludido no se vea como una distancia temporal ${ }^{133}$.

${ }^{126}$ Apud E. Alarcos Llorach, Gramática estructural, Gredos, Madrid, 1969, pág. 29.

${ }^{127}$ Cf. L. Hutcheon, op. cit., págs. 50-68. El cuadro final al que conduce la interacción de estos tres elementos, con sus respectivas características asignadas, resulta en verdad confuso y, estoy seguro, nada práctico pues, para dar inclusión a unos, discrimina arbitrariamente otros rasgos, correctamente observados, de cada elemento, con lo que, al incorporarse entre sí, los ethos resultantes ven reducidos considerablemente sus campos de acción y, por tanto, sus funciones constructivas.

${ }^{128}$ Loc. cit., pág. 11.

${ }^{129}$ The Language of Humor: Style and Technique in Comic Discourse, Longman, Londres, 1985, pág. 74. La traducción es mía.

${ }^{130}$ Cf. loc. cit., pág. 102.

${ }^{131}$ Cf. loc. cit., pág. 88 y sigs.

${ }^{132} \mathrm{Cf}$. «Irony and the Use-Mention Distinction», en P. Cole (ed.), Radical Pragmatics, Academic Press, Nueva York, 1981, págs. 295-317.

${ }^{133}$ En un contexto más amplio, para Heidegger no se trata de una diferencia necesariamente temporal en el sentido cronológico, sino, más bien, de una distancia análoga a la que media entre el lenguaje como potencia y el habla como actualización. Lo dicho se actualiza en el decir, el decir parte de lo dicho. El decir, visto como camino al habla, constituye una entidad dinámica, mientras que lo dicho corresponde al gran repertorio de lo que permanece 
Tan no es por necesidad temporal que, como señala Nash, las disonancias se atestiguan ya en el texto alusivo, al interior de su expresión y entre ésta y su contenido. Se trata de la función 'autorreflexiva' que Michele Hannoosh detecta en la parodia ${ }^{134}$, y que ha sido clave, aunque sin recibir tan preciso apelativo, en el desarrollo del modelo analítico de la crítica anglosajona contemporánea. Tal como en el seno de la escuela francesa la parodia no se comprende si no es a la luz de la intertextualidad, en la literatura especializada de habla inglesa ha ido de la mano de otro concepto muy sonado también: la 'metaficción' 135 .

El libro de Rose de 1979 es fundacional porque, aun cuando la contigüidad de ambos fenómenos había sido ya señalada ${ }^{136}$, es el primero en desarrollar un complejo teórico de la parodia sobre el fondo de la naturaleza autorreflexiva de la literatura. Para la australiana, la parodia desempeña una serie de funciones metalingüísticas desde que se articula como una superposición de códigos, como una doble codificación que deviene autorreflexividad ${ }^{137}$. Por su parte, la metaficción explotaría a tal grado estas funciones, no todas ellas exclusivas de la parodia, que el rango de autopercepción ascendería de la mera reflexividad a la conciencia para dar lugar a una ficción de la ficción en la que la parodia aporta la discontinuidad entre los códigos a manera de expresión de la autoconciencia, lo que ocurre, dice, en Beckett y en los autores franceses del 'nouveau roman' ${ }^{138}$. Una vez señalado, no obstante, el hecho innegable de que la incorporación de cada elemento a la obra literaria obedece a una motivación particular ${ }^{139}$, resulta en extremo difícil, tratándose de hechos literarios, establecer una distinción clara entre autorreflexividad y autoconciencia, de ahí que para Rose, de manera general, la parodia constituya una variante de la metaficción ${ }^{140}$.

En este marco llama mi atención que un autor más reciente como Simon Dentith renuncie casi sistemáticamente al recurso de las nomenclaturas, tan característico de las escuelas francesa y anglosajona. A cambio, en él se atestigua un regreso más auténtico a Bajtín, preocupado menos por la precisión de la terminología y más por la claridad del ejemplo. Tal vez a ello se deba que su

en el silencio, una entidad estática, potencial, de donde resulta que lo peculiar del decir no puede capturarse en un enunciado, puesto que una vez enunciado pasa a formar parte de lo dicho. Cf. De camino al habla (trad. Y. Zimmermann), Serbal, Barcelona, 1990.

${ }^{134}$ Cf. «The Reflexive Function of Parody», Comparative Literature, 41, 2, 1989, págs. 113-127.

135 Desarrollado en 1970 por William Gass en su ensayo «Philosophy and the Form of Fiction» (en Fiction and the Figures of Life, Godine, Boston, 1979, págs. 3-26) y, de manera paralela, por Robert Scholes en su artículo «Metafiction» (Iowa Review, 1, 1970, págs. 100-115), el término se refiere tanto al texto de ficción que pone en evidencia su artificialidad, como a los procedimientos mediante los que lo hace.

136 Véase L. Hutcheon, «Ironie et parodie», pág. 467.

${ }^{137}$ Cf. Parody/Meta-Fiction, pág. 51 y sigs.

138 Véase loc. cit., pág. 65.

139 Apud B. Tomachevski, «Temática», págs. 213-221.

${ }^{140}$ Cf. Parody/Meta-Fiction, pág. 65 y sigs. 
Parody (2000) parezca agregar muy poco a los argumentos del filólogo ruso, a no ser por una definición que, sin dejar de resumir la teoría en una máxima, surge de una concepción incluyente muy acorde con el espíritu bajtiniano: «La parodia comprende - asienta Dentith - cualquier práctica cultural que provea una relativamente polémica imitación alusiva de otra práctica o producción cultural» ${ }^{141}$.

\section{El contexto hispanoamericano}

Me llena de asombro que el mundo hispano vaya para un siglo de haberse olvidado casi por completo de elaborar sus propios argumentos teóricos y aun críticos al respecto de la literatura. Lo puedo llegar a entender tratándose de los países de América Latina, cuya impetuosa lozanía pudiera justificar - no digo que lo haga - la falta de madurez, la carencia de malicia ${ }^{142}$, pero ¿del entorno peninsular? ¿Dónde quedaron, me pregunto, los Fernandos de Herrera, los Gracián, los Menéndez, los Alonso? ${ }^{143}$ ¿A qué se debe que, en pleno siglo XXI, un catedrático como Juan Carlos Pueo dedique las más de ciento cincuenta páginas de Los reflejos en juego (una teoría de la parodia) (2002) a repetir puntualmente, desde el título mismo, los postulados de Linda Hutcheon y, en menor medida, de Margaret Rose, y a encontrarles correspondencias con la estética de la recepción de Wolgang Iser, las teorías vitalistas de la risa y algunas propuestas de semiótica contemporánea? No alienta más nuestro panorama. México, América Latina me atrevo a decir, nunca ha contado con grandes teóricos de la literatura y, a su muerte, los pocos grandes críticos han dejado vacíos aún no ocupados.

Es el caso de Alfonso Reyes. De manera general, el regiomontano encuentra arriesgada la renuencia a convenir en que la parodia consiste en la ridiculización de una obra o de una figura; sin embargo, en un breve ensayo de 1920 intitulado «La parodia trágica», y sin excederse en las teorizaciones, Reyes trasciende este registro al comentar las obras de Valle-Inclán, en las que suelen aparecer sujetos decididos a comportarse puntualmente como alguna figura emblemática, don Juan, por ejemplo, y conducidos por ello a toda clase de disparates, como matar a un adversario en plena plaza de la Cibeles y luego, en lugar de darse a la fuga, dedicarse a «ponderar su hazaña en unas décimas

${ }^{141}$ Routledge, Londres, pág. 9. Mías la traducción y las cursivas.

142 Tan no lo hace que, aunque contados, casos hay como el de Andrés Bello.

${ }^{143}$ La llegada de Franco al poder, en 1939, podría darse como respuesta definitiva si no fuera porque la visión panorámica comienza ya a diluirse en autores como el Pedro Salinas del exilio. Podría también argumentarse que ante la crisis sociopolítica por la que pasó España a mediados de siglo se antojaba prácticamente imposible la elaboración de visiones orgánicas y aprehensivas, aunque para estados convulsionados, ahí está Rusia, cuna del formalismo y de otras escuelas. 
retorcidas» ${ }^{144}$. Lejos de renunciar al aspecto sistémico que un año más tarde hará que el formalismo repare en la parodia, Reyes da con un material que concuerda como ninguno con dicho aspecto y que además le permite adjuntar, al efecto cómico que de él se desprende, un correlato trágico que colorea no ya el puente entre el modelo y su fantoche, sino la esencia misma de este último, su patetismo contemporáneo.

Pese al valor de su mirada, con la falta de don Alfonso el concepto abandonará región tan transparente $\mathrm{y}$, arrastrado por densos nubarrones, deberá esperar casi seis décadas para que Gustavo Pérez Firmat intente darle nueva claridad mediante su inserción en un modelo teórico de la intertextualidad ${ }^{145}$. Más que en su definición de intertexto (IT), en conformidad con sus orígenes galos, como texto dentro del texto, la peculiaridad de su enfoque se halla en que, eliminando el intertexto de un texto $(\mathrm{T})$, Pérez Firmat obtiene un sustrato denominado exotexto (ET) que lo conduce a las siguientes expresiones lógicas: $(\mathrm{ET}=\mathrm{T}-\mathrm{IT}),(\mathrm{T}=\mathrm{IT}+\mathrm{ET})$. O sea que el texto constituiría la suma de intertexto y exotexto, donde el primero se incorpora al segundo tal como el habla ajena se suma a la palabra que Bajtín llamó internamente dialógica. El cubano denomina paratexto (PT) al habla ajena y sugiere la posibilidad de que se sume al texto en calidad de intertexto en una cadena de extensión considerable, es decir, de que un intertexto refiera un paratexto que a su vez es intertexto de otro paratexto, y así sucesivamente ${ }^{146}$. Una vez restado el intertexto, Pérez Firmat divide el exotexto en tres partes, en la medida en que los elementos se sustraen de toda relación con el paratexto, función a la que asigna un carácter neutro, o se relacionan con él de algún modo ajeno al intertexto o bien desempeñan la función metalingüística de enunciar la presencia orgánica del paratexto. De manera adicional, el autor caracteriza el intertexto como un embrague que monitorea la presencia y la función de un discurso previo o, de otro modo, como intermediario entre exotexto y paratexto ${ }^{147}$.

Por cuanto a la naturaleza del intertexto, Pérez Firmat advierte dos grupos relacionales, según si hay o no compatibilidad entre exotexto y paratexto, o bien si alguno de los dos reviste una mayor presencia o ambos comparten una misma jerarquía. Las posibilidades combinatorias de estos factores condicionan cuatro categorías intertextuales: (1) compatibilidad (C) y jerarquización (J), cuando uno de los elementos predomina pero ambos se hallan en consonancia, lo que resulta en (CJ/ET): «el et adopta una posición de autoridad con respecto al PT, pero no lo contradice»148, como en la imitación, el plagio y la alusión, o bien en (CJ/PT), donde el paratexto asume la posición de privilegio, así en la glosa;

\footnotetext{
${ }^{144}$ En Obras completas, Fondo de Cultura Económica, México, IV, 1956, pág. 104.

145 Cf. "Apuntes para un modelo de la intertextualidad en literatura», Romanic Review, 69, 1978, págs. 1-14.

${ }_{146}$ Tan sólo el Banquete de los eruditos comienza parodiando el inicio del Fedón, pero sólo para remitir al Banquete platónico. Véase Ateneo, I (ep.) 1f-2a.

${ }^{147}$ Loc. cit., pág. 5.

148 Loc. cit., pág. 11.
} 
(2) compatibilidad y equivalencia (E): «el ET y el PT mantienen relaciones cordiales sin que ninguno de los dos desempeñe una función perentoria» ${ }^{149}$, de lo que resultan ciertas clases de pastiche; (3) incompatibilidad (I) y jerarquización, cuyas posibilidades serían (IJ/ET): «el et contradice, subvierte, ridiculiza el PT; la parodia, la sátira, la opinión citada y refutada» ${ }^{150}$, e (IJ/PT): cuando a la incompatibilidad se agrega la preeminencia del paratexto, lo que según el académico correspondería a la ironía, y (4) incompatibilidad y equivalencia, en los casos en que, sin resolverse a favor de ninguno, la fricción queda como polémica irresuelta, categoría en la que, apoyado en Kristeva, comprende las Poesías de Ducasse.

Resulta significativo que, al margen de la teoría citacional, Pérez Firmat resuelve el aspecto intertextual de la ironía desplazando el acontecimiento previo que condiciona la percepción de toda ironía dramática o situacional hasta ligarlo, tratándose de la ironía verbal, a la noción de paratexto, un elemento determinado, en tal caso, por las definiciones lexicológicas de los diccionarios. Semejante vía le permite llegar a una conclusión acertada, pero de inmediato lo conduce al error pues, a pesar de que la acepción convencionalmente aceptada resignifica la nueva acepción, encuentro cuestionable que en la ironía predomine la convención, el paratexto; el triunfo, por el contrario, se lo lleva el exotexto, la resignificación, con lo que desaparece la frontera que, según él, separa la ironía de la parodia. A esto se suma la ausencia total de discriminación entre esta última y la sátira - ni qué decir de la «opinión citada y refutada»-; contradecir, subvertir y ridiculizar constituyen procedimientos distintos cuya interacción no merece, de parte del cubano, precisión alguna. Circunscribir, por otro lado, la incorporación del paratexto únicamente a la fracción intertextual del texto equivale a despojar al exotexto de toda cualidad evocativa positivamente identificable, como la que avisora Lotman cuando se refiere a la estructura extratextual mediante la que el lector estabiliza la incompatibilidad de un texto paródico.

En las líneas finales de su artículo, el catedrático de Columbia rebasa, no obstante, a sus predecesores al homologar el texto con la noción más amplia e inclusiva de contexto, ya que, independientemente de la inconveniencia terminológica, sitúa el intertexto en un espacio ideológico que, como el architexto genettiano, excede lo llanamente formal. En este sentido, un excedente corresponde, sin duda, al aspecto político sobre el que, cosa nueva, Víctor Bravo ha depositado su interés en fechas más recientes. Es verdad que, en el marco de su caracterización de la conciencia irónica y sin establecer límites o intersecciones entre unos y otros, el venezolano sitúa la paradoja, el absurdo y lo grotesco en idéntica jerarquía que la parodia, pero no lo es menos que cuando se refiere en específico a esta última detecta en ella, como hace Nash, un instrumento de poder $\mathrm{o}$, más precisamente, un instrumento contra el poder ${ }^{151}$.

\footnotetext{
${ }^{149}$ Loc. cit., pág. 12.

${ }^{150}$ Loc. cit.

${ }^{151}$ Cf. Ironía de la literatura, Universidad de Zulia, Maracaibo, 1993, pág. 97 y sigs.
} 
Para Bravo, la parodia es a la vez crítica y reflexión, conciencia de lo diferente expresada desde la identidad, y su registro se manifiesta en tres grandes esferas: la literatura, la cultura y el poder, de donde su importancia en lo tocante a la percepción de lo real y, en especial, de sus discontinuidades. Esta percepción de lo real y su consecuente desmantelamiento son para Bravo tareas de la conciencia colectiva, asunto que, si bien menciona de pasada, obviando sus implicaciones en el marco de lo social, posee relevancia a la luz de otro tema no contemplado abiertamente por él; esto es, la comedia.

\section{Reflexión final}

Más que la obtención de un destilado mediante el que pudiere elaborarse el paradigma teórico de la parodia, me interesa aquí subrayar, a la luz del corpus reflexivo que ha generado occidente sobre el tema pero, más aún, a la luz de la literatura paródica que atraviesa la cultura occidental prácticamente desde sus inicios, las líneas de continuidad que han hecho de la parodia un fenómeno identificable independientemente de los contextos en que se manifiesta. Antes que ampliar el concepto de parodia para ajustarlo a las necesidades del arte de algún periodo de la historia, propongo observar la amplitud que el propio concepto ha cobrado para ajustarse de siempre a las exigencias de cualesquiera estilos y corrientes artísticos. Situada de inicio en la gran distancia que media entre un género de épica burlesca y un procedimiento de citación cómica reducible a un verso o una frase, dicha amplitud permite esbozar una concepción de la parodia a la vez incluyente y específica. En los términos de dicha integridad, quisiera primero recuperar la definición de los formalistas, para quienes la parodia supone el refuncionamiento cómico de un procedimiento mecanizado, para enseguida ocuparme brevemente de sus implicaciones en el marco del recorrido histórico recién expuesto.

Nadie pone en entredicho, a propósito, que parte del éxito de Hiponacte y Hegemón, de Cervantes, Flaubert y Bolaño, radica en que, antes de sus respectivas llegadas, la épica homérica, los libros de caballerías, la novela sentimental y el género detectivesco se habían mecanizado al grado de convertirse en estándares, en modelos operacionales que, más que lo anecdótico, comprometían los procedimientos estilísticos y retóricos de la producción literaria. Lo mismo ha de decirse de Aristófanes en relación con los tragediógrafos y también, se me ocurre, de Carpentier por cuanto a Descartes o los enciclopedistas, donde el compromiso abarca cuestiones más allá de lo literario. La necesidad, pues, de un modelo pero, sobre todo, de que dicho modelo se haya prestado al abuso parece incuestionable; ello, a pesar del esfuerzo de una Linda Hutcheon para soslayar la mecanización inherente a todo procedimiento parodiado. Por lo que hace al refuncionamiento, nadie como los teóricos del dieciocho para detectar la transferencia de la argumentación de un sujeto a otro o, de otro modo, la atribución de la palabra mediante la que la parodia 
transfigura el modelo y en la que de siempre se ha observado una inversión entre lo alto y lo bajo. De ahí la comicidad del refuncionamiento, cuya triple vía: repetición, inversión e interferencia de las series ${ }^{152}$, explota Twain en todo su esplendor en El principe y el mendigo.

Se pierde de vista, sin embargo, que la comicidad no es el refuncionamiento, sino que mediante la comicidad se obtiene cierta clase de refuncionamiento que, en términos retóricos, comprende una reflexión negativa sobre la escritura, en la que detecta la posibilidad misma e, incluso, la necesidad de su reversión; es decir, el germen de su perversión, que la parodia adopta como plataforma para significar. En este sentido, y en atención a la nomenclatura de Bajtín, el consenso general apunta a la bivocalidad de la parodia; no obstante, muy pocos se han ocupado de esa segunda voz que no es la del modelo y que, tratándose, como bien apunta Lotman, de una reestructuración, conlleva necesariamente una resignificación, un mensaje propio, pues. Por cuanto al nivel del intertexto, que yo sepa sólo Bouché ha reparado en la crítica sustancial del lenguaje, de su propio lenguaje, que la parodia pone en marcha en tanto que forma del contenido de toda figuración irónica. A cambio, pese a haberse a la postre desdicho, me parece que únicamente Hutcheon ha observado con tino la naturaleza del exotexto, naturaleza, en cualquier caso, satírica desde que, en tanto que sustancia del contenido irónico ${ }^{153}$, enuncia de manera velada una crítica del mundo contemporáneo. No es tanto con los autores de libros de caballerías con quienes se ensaña Cervantes como con los lectores que en pleno siglo XVI evidencian la desproporción entre un mundo idealizado y una realidad depravada. En su calidad de estrategia retórica, la máscara paródica resulta necesaria para ocultar la crítica tras el discurso mediante una suerte de falsa objetividad o, diría Nash, de alusión controlada. Ocurre que cuando, así en Carpentier, por ejemplo, pero también en el Don Juan de Byron, la crítica se satura y los elementos satíricos predominan ${ }^{154}$, la comicidad palidece, sin llegar nunca a desaparecer por completo, hasta convertirse en una forma reducida de la risa carnavalesca ${ }^{155}$, aquella que, si por debajo, acompaña todo acontecer trágico.

De todo esto se desprende la dificultad con que se han topado los teóricos a la hora de deslindar la parodia de otras nociones tradicionalmente ligadas al registro irónico de la comunicación, con la sátira y la comedia a la cabeza. Con

${ }_{152}$ Cf. H. Bergson, La risa (s. trad.), en Introducción a la metafísica; La risa, Porrúa, México, 1986, págs. 78-82.

153 Para una comprensión cabal, en el marco de la lingüística, de las nociones forma del contenido y sustancia del contenido, véase L. Hjelmslev, Prolegómenos a una teoría del lenguaje (trad. José Luis Diáz de Liaño), Gredos, Madrid, 1974, págs. 79-87.

${ }_{154}$ No es casual, por cierto, la consonancia de los términos «satura»y «satírico» desde que comparten un mismo origen. Véanse G. Hendrickson, «Satura-The Genesis of a Literary Form», Classical Philology, 6, 2, 1911, págs. 129-143, R. Henning Webb, «On the Origin of Roman Satire», Classical Philology, 7, 2, 1912, págs. 177-189, y B. Ullman, «Satura and Satire», Classical Philology, 8, 2, 1913, págs. 172-194.

${ }^{155}$ Cf. M. Bajtín, Problemas de la poética de Dostoievski, págs. 242-245. 
estas páginas pretendo haber despejado, aunque en grado mínimo, la controversia, si bien convengo en que aún hacen falta trabajos análogos a propósito, y en específico, de dichas nociones. Hasta ahora me he ocupado de efectuar, también, el estudio correspondiente a la ironía ${ }^{156}$, pero aprovecho la ocasión para asumir el compromiso de completar y compartir los que atañen a otros términos en juego.

${ }_{156}$ Cf. J. Campesino, Estética de la ironía, Editorial Académica Española, Madrid, 2016, págs. 15-85. 